\title{
USEFULNESS OF SELECTED INCISOR CHARACTERISTICS FOR DETERMINING THE AGE OF HUCUL HORSES*
}

\author{
Jarosław Łuszczyński, Magdalena Pieszka \\ Department of Horse Breeding, University of Agriculture in Krakow, \\ Al. Mickiewicza 24/28, 30-059 Kraków, Poland \\ Corresponding author: mpieszka@ar.krakow.pl
}

\begin{abstract}
The aim of this study was to assess the suitability of selected characteristics of incisors for age determination in Hucul horses. The study included 173 Hucul horses (137 mares, 28 stallions and 8 geldings) from one day to 27 years of age. Breeding documentation was used to determine the actual age of the horses, which were then divided into age groups. Each group of horses was assigned a specific incisor characteristic to help identify their age. Selected incisor characteristics were used to evaluate the age of the horses according to the method reported by Pruski (2007) and the results were compared with the actual age, indicating the percentage of errors made. It was found that most errors were made in the case of horses over 11 years old, when assessing the changing shape of the occlusal surface of incisors (Table 1). In this group the percentage of errors was significantly higher $(\mathrm{P} \leq \mathbf{0 . 0 1})$ than that found for horses from the first three youngest age groups, in which the eruption time of deciduous incisors, the disappearance of cups on deciduous incisors and the eruption time of permanent incisors were taken into account. Compared to the above traits, errors were made significantly more often $(\mathrm{P} \leq 0.01)$ when age was determined based on the disappearance of permanent incisors, in a group of horses aged between 6 and 11 years. The eruption time of deciduous incisors and permanent incisors were the traits which enabled the most accurate determination of the horses' age. The results obtained suggest that age determination based on dentition is not accurate enough and can only play a subsidiary role, for example when no breeding records are available.
\end{abstract}

Key words: incisors, age, Hucul horses

Hucul horses have been around since the late 17th century. This breed was created in Bukovina and Eastern Carpathians, but its origin has not been fully elucidated until now. It is highly probable that they carry Tarpan and Przewalski's horse blood in their veins, and for many years Hucul horses were crossed and improved using various breeds and types of horses. However, it is under the influence of the austerity

\footnotetext{
*Supported by grant N N311 315935 financed by the Ministry of Science and Higher Education.
} 
of the Carpathian Mountains and the associated harsh living conditions that Hucul horses developed unique conformation characteristics, including very strong teeth.

Morphological analysis of teeth can be used to determine the type of food eaten or the type of environment in which the horses lived. Both during the horses' lifetime and many years after their death, the appearance of teeth may also indicate the age, gender or health status of the examined animal.

In contrast to the rabbit (hypselodont teeth) and the dog or the cat (brachydont teeth), horse incisors are classified as hypsodont, with delayed termination of root formation and prolonged dental growth and eruption (Muylle et al., 1999 b).

Due to the special characteristics of the incisors and the changes that they constantly undergo, a number of methods and patterns have been used over the years for accurate determination of the horses' age. However, recent research conducted by many authors suggests that some of these characteristics cannot be regarded as reliable indicators of actual age because of distinct interindividual, breed and environmental differences, or those caused by the type of feed consumed (Walmsley, 1993; Richardson et al., 1994, 1995 a; Muylle et al., 1997, 1998, 1999 b; Vollmerhaus et al., 2002; Friker et al., 2006; Nicks et al., 2007).

According to Lowder and Mueller (1998), veterinarians and equine practitioners should be able to determine the age of horses by means of dentition. This ability would be useful to many owners or users of Hucul horses, at least to a limited extent, considering a recent increasing interest in their use in areas such as recreation, amateur sports, agritourism or hippotherapy. It could also come in useful when buying and insuring a horse, planning its future career or performing therapeutic procedures.

The aim of this study was to assess the suitability of selected incisor characteristics for age determination in Hucul horses.

\section{Material and methods}

The study included 173 Hucul horses (137 mares, 28 stallions and 8 geldings) from one day to 27 years of age. To eliminate the influence of diet on the attrition of incisors, all the horses came from one breeding centre, the Hucul Stud Farm Gładyszów, where they were fed consistently according to age group. In the summer season, horses used pasture forage and were supplemented with meadow hay and crushed oats. Winter feeding was based on meadow hay and crushed oats. From the second year of age, hay was partly replaced with ensiled hay.

Each horse was identified by reading information from the implanted microchip. Breeding documentation was used to determine the actual age of the horses, which were then divided into age groups. Each group of horses was assigned a specific incisor characteristic to help identify their age (Table 1).

Dental examination was carried out by a person not specializing in equine dentistry. After inserting a hand into the horse's mouth at the diastema, the tongue was pulled out of the mouth to prevent the mouth closing. Visible incisors in the 
lower and upper jaw were examined visually for specific characteristics, and the observed results were recorded in a table. Selected incisor characteristics were used to evaluate the age of the horses according to the method reported by Pruski (2007) (Table 2) and the results were compared with actual age, indicating the percentage of errors made.

Table 1. Percentage of age assessment errors based on selected traits in comparison to the actual age of Hucul horses

\begin{tabular}{lllll}
\hline \multicolumn{1}{c|}{ Age group (years) } & \multicolumn{1}{c|}{ Dental criterion } & $\mathrm{n}$ & \multicolumn{1}{c}{$\%$ errors } \\
\hline $0-0.5$ & Eruption of deciduous incisors & 33 & $12 \mathrm{Aa}$ \\
$>0.5-2.5$ & Disappearance of the cups on deciduous incisors & 29 & $38 \mathrm{ACb}$ \\
$>2.5-6$ & Eruption of permanent incisors & 58 & $19 \mathrm{~A}$ \\
$>6-11$ & Disappearance of the cups on permanent incisors & 32 & $56 \mathrm{BC}$ \\
$>11$ & Modifications of incisor shape & 21 & $81 \mathrm{~B}$ \\
\hline
\end{tabular}

$\mathrm{a}, \mathrm{b}-$ values in columns with different letters differ significantly $(\mathrm{P} \leq 0.05)$.

$\mathrm{A}, \mathrm{B}, \mathrm{C}-$ as above for $\mathrm{P} \leq 0.01$.

Table 2. A method for assessing the horse's age based on the appearance of teeth (Chachuła et al., 1984) compared to the age ranges observed in Hucul horses

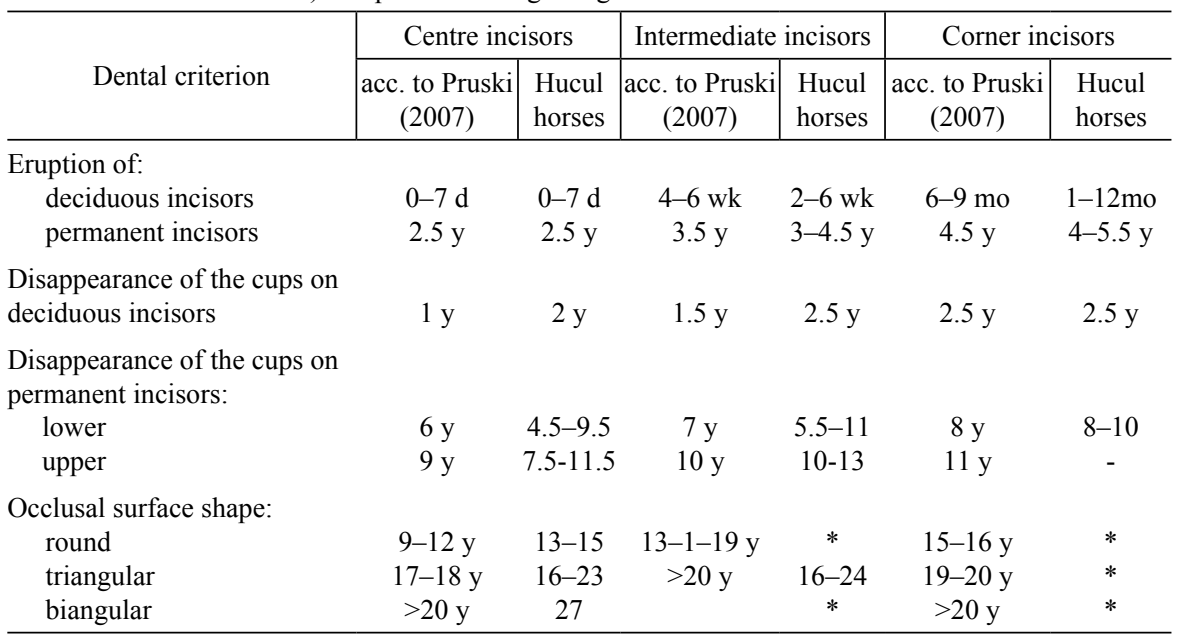

- No observations.

* The shape of the occlusal surface of the incisors was not conclusively determined.

The results were analysed statistically using the SAS computer program (2001). Significance of differences between the age groups was determined by the Chisquare test.

\section{Results}

When analysing the effectiveness of the method for determining age based on selected dentition characteristics, it was found that most errors were made in the 
case of horses over 11 years old, when assessing the changing shape of the occlusal surface of incisors (Table 1). In this group the percentage of errors (81\%) was significantly higher $(\mathrm{P} \leq 0.01)$ than that found for horses from the first three youngest age groups, in which the eruption time of deciduous incisors, the disappearance of cups on deciduous incisors and the eruption time of permanent incisors were taken into account. Compared to the above traits, errors were made significantly more often $(\mathrm{P} \leq 0.01)$ when age was determined based on the disappearance of permanent incisors, in a group of horses aged between 6 and 11 years. The eruption time of deciduous incisors and permanent incisors were the traits which enabled the most accurate determination of the horses' age. In the groups of horses in which this parameter was used, the percentage of errors was only $12 \%$ and $19 \%$, respectively.

In foals from birth to 6 months of age, the main cause of incorrect age determination was the premature eruption of intermediate and corner incisors (Table 2). In some animals, deciduous intermediate incisors were observed to erupt at the age of 2 weeks and corner incisors as early as the end of the first month of age. In horses aged between 6 months and 2.5 years, cups in the centre and deciduous intermediate incisors disappeared about one year later than the relevant method would suggest. In another group, the wrong age determination was due to a year-long delay in the exchange of both intermediate and corner incisors with permanent incisors. In horses aged 6 to 11 years, the later than expected disappearance of the cups was observed most often, with the difference in relation to the method compared reaching 3 years. In three animals, the cups on lower centre and intermediate incisors as well as on the upper centre incisors were gone about 1.5 years earlier. Because this group comprised no horses aged 11 and 12 years, no time interval for the disappearance of cups on the upper corner incisors was established. In horses over 11 years of age, the age was overstated because of an earlier change in the shape of the occlusal surface of incisors from round to triangular. The opposite situation was found in one animal. Most often, however, it was not possible to conclusively determine the shape of the occlusal surfaces of incisors, especially the corner incisors, which was the main reason for a high percentage of errors when determining the correct age of horses in this group.

\section{Discussion}

We noted a tendency whereby the older the Hucul horses were, the more difficult it was to successfully determine their age using the incisor characteristics. A similar correlation was found by Richardson et al. (1995 a) in Thoroughbred horses and by Muylle et al. (1998), who compared the teeth of Arabian horses with trotter and Belgian draft horses. The analysis performed by Nicks et al. (2007) showed that differences between actual age and that estimated from dentition in horses up to 8 years of age are lower than in older horses. According to Richardson et al. (1994), there was a positive correlation between the actual and "dental" age in horses up to 5 years old, after which the differences increased and the accuracy of age determination 
became much lower in horses older than 11 years. The same authors concluded that disappearance of the cups on permanent incisors was a reliable trait when determining the horses' age.

According to Muylle et al. (1999 a), horse incisors wear down at a rate of about $2.5 \mathrm{~mm}$ a year. However, this rate may be dependent on many factors, such as those related to the breed (Gáspárdy et al., 2009). Muylle et al. (1997) proved that the incisors of draft horses wore down more rapidly than those of trotter horses, and showed in another study (Muylle et al., 1999 c) that Arabian horses had much harder enamel and dentine compared to the breeds cited above. Therefore, it seems that disappearance of the cups cannot be a reliable indicator of the actual age of horses of different breeds. In Hucul horses this characteristic was of little use because a mistake was made in more than half of the cases, which was probably due to the fact that incisors wore down more slowly than expected. Likewise, Muylle et al. (1996) observed that proper determination of age based on the disappearance of cups is less effective than when other characteristics are used. This indicator also did not work for Mini Shetland ponies and donkeys (Muylle et al., 1999 b), one of the reasons being the differences in the depth of the cups and the way they were located on the corner incisors.

In Hucul horses, determination of age from the shape of the occlusal surface of incisors proved even less reliable compared to the disappearance of cups. Because a triangular shape on the lower centre and intermediate incisors appeared 2-3 years earlier than expected, only the age of every fifth horse was determined correctly. Similar observations were made for Belgian draft mares (Nicks et al., 2007), in which the change in shape from round to triangular and biangular also occurred earlier on the same teeth.

In our study, we established that the most useful indicator for determination of age was the eruption time of deciduous and permanent incisors. A small number of irregularities were related to the premature eruption of deciduous intermediate and corner incisors and their subsequent exchange with permanent teeth. In Shetland ponies and donkeys, both of these phenomena occurred later than expected (Muylle et al., 1999 b). Nevertheless, Muylle et al. $(1996,1997)$ claimed that in other breeds of horses these two characteristics, in addition to the appearance of the dental star, were the most reliable in the assessment of a horse's age. Also Nicks et al. (2007) found that the exchange of deciduous with permanent incisors occurred in the expected period. However, Richardson et al. (1995 b) considers that eruption of incisors is a constant but rather unreliable characteristic.

Our results and those of other authors suggest that estimating age based on the appearance of teeth is not accurate enough particularly when dental examination is carried out by a person not specializing in equine dentistry and is only based on the characteristics described in this study. However, it is expected that the method used since purposeful breeding work also presently may be applicable in certain situations. After the introduction of electronic identification together with prevention of horses marking by burning or freezing, the method for determining age based on the appearance of teeth can play a subsidiary role, for example, when no breeding records are available. 
In addition, for Hucul horses, which are a conservative breed kept in closed breeding, any additional information about their specific features, in this case the teeth, can contribute to a better understanding of the breed and improve the system of animal management and veterinary practice. But the course of changes in the incisors depends to a large extent on traits specific to an individual or breed, and it seems impossible to establish a single universal pattern of age determination for different horse breeds. Even the use of computer models, which take into account the characteristics of teeth correlated with the actual age, or an assessment by experienced clinicians may produce unsatisfactory results (Richardson et al., $1995 \mathrm{c}$ ). To improve the effectiveness of age estimation, age ranges characteristic of certain breeds or types of horses could be determined. Account should also be taken of other incisor characteristics such as the dental star, Galvayne's groove, the mark of mouth and hook, the importance of which was stressed by many authors (Richardson et al., 1994, 1995 b; Muylle et al., 1996, 1997; Pasca et al., 2006). However, the proper identification and classification may require an excellent knowledge of the dental anatomy of horses.

\section{References}

Friker J., Dias D.P., Zeiler E. (2006). Breeds-based differences in age determination in Thoroughbred, Arab, Trotter and Belgian Draft. Wien. Tierarztl. Monat., 93: 218-225.

Gás párdy A., Ri eden S., S i mon y i Z., S ze mere B., B od ó I. (2009). Characterization of age dependent alterations of the cup of the incisor on the basis of data from Hungarian and German Horses. Berl. Munch. Tierarztl. Wochenschr., 122: 132-139.

L ow de r M.Q., M u e 11 e r P.O. (1998). Dental embryology, anatomy, development, and aging. Vet. Clin. N. Am. Equine, 14: 227-245.

Mu ylle S., S i moens P., L a uwers H. (1996). Ageing horses by an examination of their incisor teeth: an (im)possible task?, Vet. Rec., 138: 295-301.

Muylle S., S i moen s P., La uwers H., Van Loon G. (1997). Ageing draft and trotter horses by their dentition. Vet. Rec., 141: 17-20.

Muylle S., Simoens P., Lauwers H., Van Loon G. (1998). Ageing Arab horses by their dentition. Vet. Rec., 142: 659-662.

Mu y 11 e S., S i m o e n s P., Lauwers H. (1999 a). Age-related morphometry of equine incisors. Zbl. Vet. Med. A., 46: 633-643.

Muylle S., Simoens P., Lauwers H., Van Loon G. (1999 b). Age determination in miniShetland ponies and donkeys. Zbl. Vet. Med. A., 46: 421-429.

Mu ylle S., S i m o en s P., V e rb e e k R., Y s e baert M.T., L a u wer s H. (1999 c). Dental wear in horses in relation to the microhardness of enamel and dentine. Vet. Rec., 144: 558-561.

Nicks B., Delfontaine B., Claveau C., Ferrari S., Canart B., Vandenheede M. (2007). Accuracy of ageing horses by their dentition: results of a study on Belgian draft mares. Ann. Med. Vet., 151: 6-14.

P a s c a I., P ust a D., M or ar R., D a b o c i O., S a m o il a D. (2006). Objective indicators regarding the horses age identification according to their dentition. Clujul Med. Vet., 10: 48-52.

Pr u s k i W. (2007). Hodowla koni. PWRiL, Warszawa, Poland, pp. 179-184.

Richardson J.D., Cripps P.J., Hillyer M.H., O'Brien J.K., Pinsent P.J., Lane J.G. (1995 a). An evaluation of the accuracy of ageing horses by their dentition: a matter of experience? Vet. Rec., 137: 88-90.

Richardson J.D., Cripps P.J., Lan e J.G. (1995 b). An evaluation of the accuracy of ageing horses by their dentition: changes of dental morphology with age. Vet. Rec., 137: 117-121. 
Richardson J.D., Cripps P.J., Lane J.G. (1995 c). An evaluation of the accuracy of ageing horses by their dentition: can a computer model be accurate? Vet. Rec., 137: 139-140.

Richards on J.D., L a n e J.G., W a ldron K.R. (1994). Is dentition an accurate indication of the age of a horse? Vet. Rec., 135: 31-34.

Vollmerhaus B., Roos H., Knospe C. (2002). The origin and function of the enamel cup, infundibulum dentis, on the incisors of the horse. Anat. Histol. Embryol., 31: 53-99.

W a $1 \mathrm{~m} \mathrm{~s}$ le y J.P. (1993). Some observations on the value of ageing 5-7-year-old horses by examination of their incisor teeth. Equine Vet. Educ., 5: 295-298.

Accepted for printing 26 VIII 2011

\section{JAROSŁAW ŁUSZCZYŃSKI, MAGDALENA PIESZKA}

\section{Przydatność wybranych cech zębów siecznych do określania wieku u koni huculskich}

\section{STRESZCZENIE}

Celem niniejszej pracy była próba oceny przydatności wybranych cech zębów siecznych do określania wieku u koni huculskich. Badaniami objęto 173 konie rasy huculskiej (137 klaczy, 28 ogierów i 8 wałachów) w wieku od pierwszego dnia po urodzeniu do 27 lat. Na podstawie dokumentacji hodowlanej określono rzeczywisty wiek koni, które następnie podzielono na grupy wiekowe. Każdej grupie przyporządkowano określoną cechę zębów siecznych umożliwiającą rozpoznanie wieku. Na podstawie wybranej cechy siekaczy oceniono wiek koni według metody podanej przez Pruskiego (2007), a wynik porównano z wiekiem rzeczywistym, podając procent popełnionych błędów. Najwięcej błędów popełniono w przypadku koni powyżej 11. roku życia, oceniając zmianę kształtu powierzchni trącej siekaczy (tab. 1). W tej grupie procent nieprawidłowych ocen był wysoko istotnie wyższy od wykazanego dla koni z pierwszych trzech najmłodszych grup wiekowych, w których brano pod uwagę czas wyrzynania siekaczy mlecznych, zanikanie rejestrów na siekaczach mlecznych i czas wyrzynania siekaczy stałych. Wysoko istotnie częściej w porównaniu do wymienionych wyżej cech mylono się także przy ustalaniu wieku na podstawie zanikania rejestrów na siekaczach stałych w grupie koni od 6 do 11 lat. Cechami, które pozwalały najdokładniej określić właściwy wiek koni, okazały się: czas wyrzynania siekaczy mlecznych i siekaczy stałych. Przedstawione wyniki sugerują, że szacowanie wieku na podstawie wyglądu uzębienia nie jest zbyt precyzyjne i może pełnić tylko pomocniczą rolę, np. gdy brak jest dokumentacji hodowlanej. 